archives

of thermodynamics

Vol. 36(2015), No. 3, 123-138

DOI: $10.1515 /$ aoter-2015-0025

\title{
Analysis of nodalization effects on the prediction er- ror of generalized finite element method used for dynamic modeling of hot water storage tank
}

\author{
MARCIN WOEOWICZ ${ }^{a 1}$ \\ JAKUB KUPECKI ${ }^{b}$ \\ KATARZYNA WAWRYNIUK ${ }^{b}$ \\ JAROSEAW MILEWSKI ${ }^{a}$ \\ KONRAD MOTYLIŃSKI ${ }^{b}$
}

a Institute of Heat Engineering, Warsaw University of Technology, Nowowiejska 21/25, 00-665 Warsaw, Poland

$b$ Thermal Processes Department, Institute of Power Engineering, Augustówka 36, 02-981 Warsaw, Poland

\begin{abstract}
The paper presents dynamic model of hot water storage tank. The literature review has been made. Analysis of effects of nodalization on the prediction error of generalized finite element method (GFEM) is provided. The model takes into account eleven various parameters, such as: flue gases volumetric flow rate to the spiral, inlet water temperature, outlet water flow rate, etc. Boiler is also described by sizing parameters, nozzle parameters and heat loss including ambient temperature. The model has been validated on existing data. Adequate laboratory experiments were provided. The comparison between 1-, 5-, 10- and 50-zone boiler is presented. Comparison between experiment and simulations for different zone numbers of the boiler model is presented on the plots. The reason of differences between experiment and simulation is explained.
\end{abstract}

Keywords: Dynamic modeling; Hot water storage tank

\footnotetext{
${ }^{1}$ Corresponding Author. E-mail: marcin.wolowicz@itc.pw.edu.pl
} 


\section{Introduction}

Rising fuel prices and increasing electricity consumption are driving the research into more efficient electricity and heat generation sources $[2,3,11,13$, $16,18]$, additional limits are created by $\mathrm{CO}_{2}$ emission reduction requirements $[4,14,20,21,25]$. Energy used for space and domestic water heating constitutes $1 / 3$ of the total energy used in industrialized countries like Poland. Fossil fuel consumption and emissions may be reduced by using solar-based technologies. For electricity generation, solar energy may be used directly (photovoltaic panels) or indirectly utilizing biofuels $[5,12,27]$ applying, for example, fuel cell technology which additionally features high efficiency due to the direct transformation of chemical energy into electricity $[1,6,10,15,17,19,23,24,26]$. Small combined heat and power (CHP) systems may become efficient sulutions. Consumption of electricity and heat goes not parallel, so one of the ideas is to connect fuel cell to the boiler. Boiler can storage hot water which can be used even when fuel cell is not in operation (covering the demand for hot water), and on the other hand, fuel cell can load the boiler with hot water when electricity is needed, but there is no demand for hot water. The aim of this work is to develop a mathemetical model of hot water storage tank (boiler) and validate it based on experimental data.

\section{Boiler modeling - literature review}

The analysis of boiler modeling was made by several authors. An experimental investigation of the thermal performance of an improved design for storage-type domestic electric energy heater was carried out in [9]. The performance, in terms of water outflow temperature profile and discharging efficiency was compared with that of conventional comparable design units of $50 \mathrm{dm}^{3}$ tank capacity and $1.2 \mathrm{~kW}$ power rating. The transient temperature-distributions in the storage water during hot/cold water discharging/charging process indicated the effectiveness of the horizontal wedged-pipe inlet in promoting thermal stratification inside such small size tanks, this had a direct impact on the heater performance as indicated by the higher discharging efficiency values.

A software simulation model of the behavior of a stratified-store was developed and validated against measured data in [22]. The model takes into account the dynamic thermal behaviors of the store and the immersed heat 


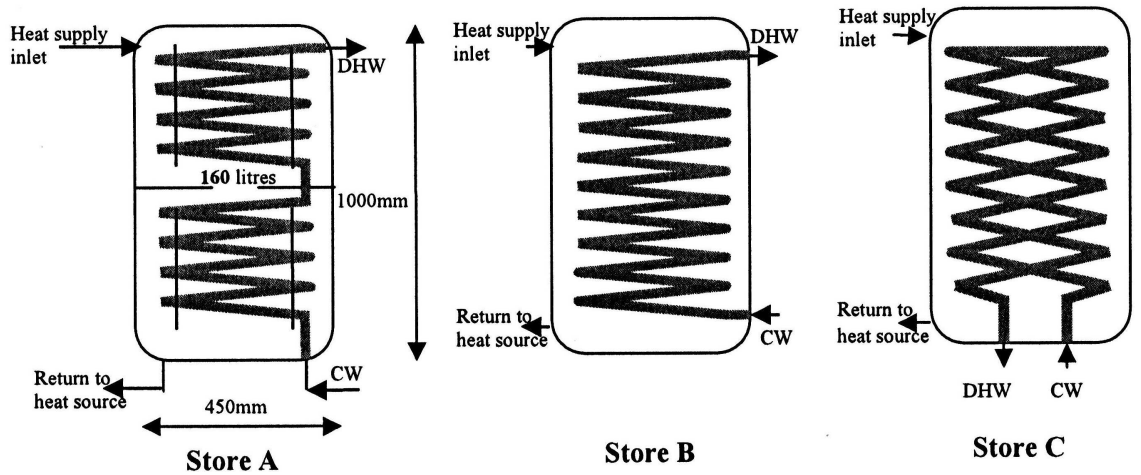

Figure 1: Schematic designs of stores A, B and C as in the analysis [22].

exchanger (HX) feed by cold water (CW) and their effects on the predicted domestic hot water (DHW) temperatures. The validation showed good general agreement between experiment and simulation. The differences in the energy of the withdrawn DHW for the measurements and predictions were about $0.6 \%$. The sophisticated inner configuration of the novel store improved its performance by up to $15 \%$. The store with the downwards coiled HX pipe showed adverse effects and a decreased performance by up to $20 \%$. The immersed HX position should be coiled upwards and located in the upper part of the tank in order to achieve a high rate of heat-extraction - see Fig. 1.

The dynamic operation of a full-scale domestic electric hot water storage tank with a capacity of $150 \mathrm{dm}^{3}$ equipped with three different inlet and two outlet ports for outflow rates of 5,10 , and $15 \mathrm{dm}^{3} / \mathrm{min}$ has been experimentally analyzed in [7].

The experimental investigation on the performance of the space/water heating system using an on demand external domestic hot water production system with different control strategies is reported in 8 - see Fig. 2. The tested domestic hot water production systems consisted of a plate heat exchanger, a circulating pump, a flow switch and a thermostatic regulation valve. The storage tank used is a full scale commercial model of $500 \mathrm{dm}^{3}$ capacity. It consists of a cylindrical body and two Klopper-type caps, made of $2 \mathrm{~mm}$ thick stainless steel (AISI 316) sheets and with both caps welded to the body. The tank is $2.110 \mathrm{~mm}$ high and $580 \mathrm{~mm}$ in diameter, with an aspect ratio of 3.64. $80 \mathrm{~mm}$ thick rockwool sheets are used to prevent heat 


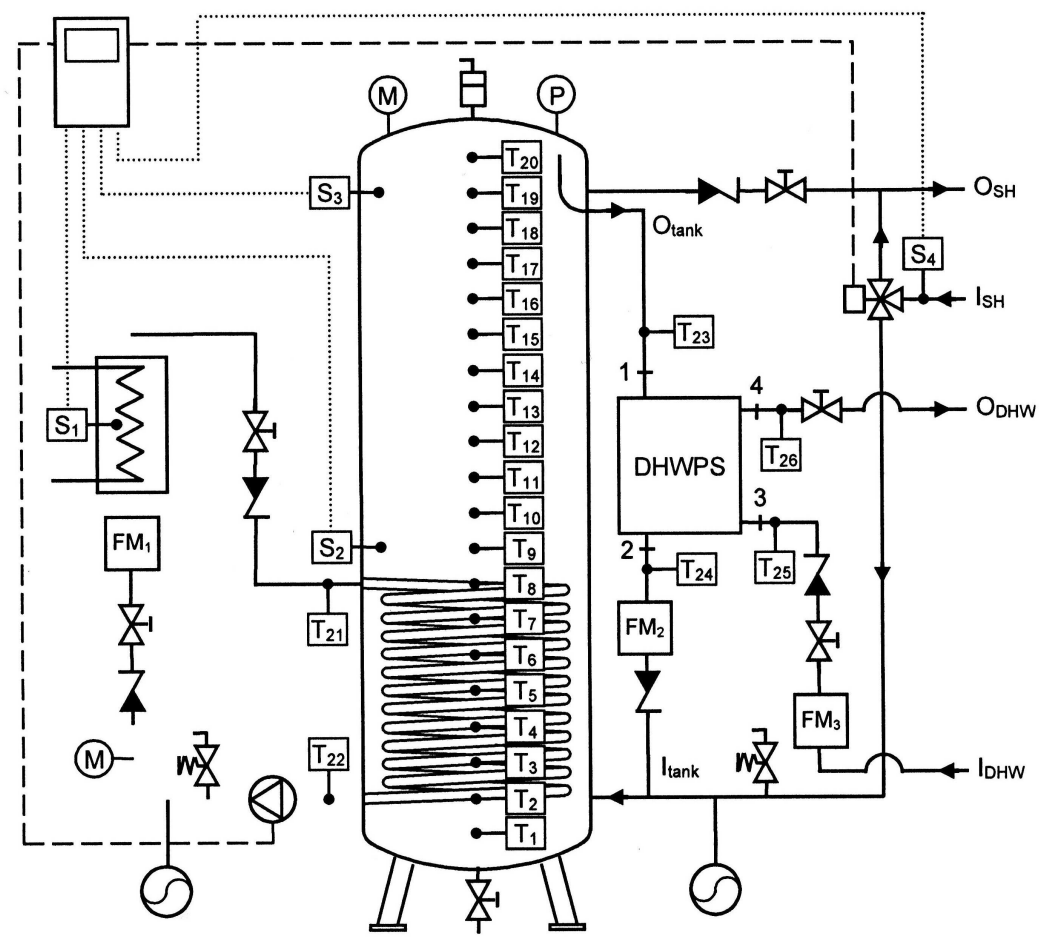

Figure 2: Sketch of the experimental setup [8], M - pressure gauge, $\mathrm{P}$ - pressure transducer, $\mathrm{S}_{i}-\mathrm{S}_{4}-$ control panel sensor, $\mathrm{T}_{21}-\mathrm{T}_{26}$ - data acquisition system sensor, $\mathrm{FM}_{1}-\mathrm{FM}_{3}$ - flow meter, $\mathrm{O}_{S H}-$ outlet at space heating side, $\mathrm{I}_{S H}$ - inlet at space heating side, $\mathrm{I}_{\text {tank }}$ - inlet at tank side, $\mathrm{I}_{D H W}$ - inlet of domestic hot water, $\mathrm{O}_{D H W}$ - outlet of domestic hot water, $\mathrm{O}_{\text {tank }}$ - outlet at tank side, DHWPS domestic hot water production system.

losses from the stored water to the surroundings. It is equipped with an immersed helical coil heat exchanger placed at the bottom of the tank, as can be seen in Fig. 2. The coil is made of stainless steel (AISI-316L) tube of $33 / 30 \mathrm{~mm}$ outer/inner diameters and consists of 12 loops with a total length of $17 \mathrm{~m}$, including the inlet and outlet sections. Experiments have been performed heating the water in the tank up to $80^{\circ} \mathrm{C}$ and considering domestic hot water draw-off flow rates of $5,10,15$ and $20 \mathrm{dm}^{3} / \mathrm{min}$ at a set temperature of $45^{\circ} \mathrm{C}$. In the study the thermal behavior of the four domestic hot water production systems is analyzed and compared, as well as its effects on the thermal performance of the tank during consumption 
operation. Results show that the control strategy of the domestic hot water production system significantly influences the quality of the domestic hot water supply and the thermal performance of the storage tank.

\section{Theory}

A P-H flash [28] (pressure-enthalpy calculations) is performed to determine the product conditions and phases. The pressure at which the flash is performed is the lowest feed pressure minus the pressure drop across the vessel. The enthalpy is the combined feed enthalpy plus or minus the duty (for heating, the duty is added; for cooling, the duty is subtracted).

Vessel has the ability to store significant amount of holdup. For the vessel, the heat flow is calculated as follows:

$$
\text { Heat Flow }=U A\left(T_{A m b}-T\right),
$$

where: $U$ - the overall heat transfer coefficient, $A$ - the heat transfer area, $T_{A m b}$ - the ambient temperature, $T$ - holdup temperature.

Heat Flow is defined as the heat flowing into the vessel. The heat transfer area is calculated from the vessel geometry. The Steady-State mode vessel energy balance is defined as

$$
H_{\text {feed }} \pm \text { Duty }=H_{\text {vapour }}+H_{\text {heavy }}+H_{\text {light }},
$$

where: $H_{\text {feed }}$ - heat flow of the feed streams, $H_{\text {vapour }}$ - heat flow of the vapor product stream, $H_{\text {heavy }}$ - heat flow of the light liquid product stream, $H_{\text {light }}$ - heat flow of the heavy liquid product stream.

The pressure drop is defined as

$$
P=P_{I}=P_{\text {feed }}-D P,
$$

where: $P$ - vessel pressure, $P_{I}$ - pressure of liquid product stream(s), $P_{\text {feed }}$ - pressure of feed stream, $D P$ - pressure drop in vessel.

The amount of liquid volume, or holdup, in the vessel at any time is given by the following expression:

$$
\text { Holdup }=\text { Vessel Volume } \frac{P V(\text { Full })}{100},
$$

where: $P V(F u l l)$ - liquid level in the vessel at time $t$.

Heat is lost (or gained) from the holdup fluid through the wall and insulation to the surroundings. 


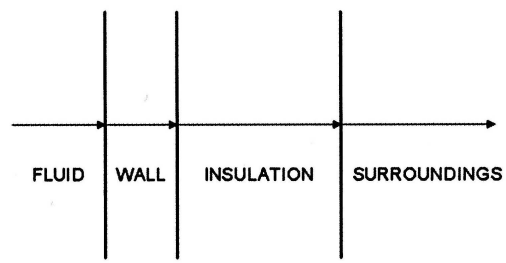

Figure 3: Heat loss model.

A balance can be performed across the wall:

$$
\begin{aligned}
& \frac{d}{d t}\left(A x_{\text {wall }} C p_{\text {wall }} T_{\text {wall }}\right)= \\
& \quad=h_{\text {fluid,wall }} A\left(T_{\text {fluid }}-T_{\text {wall }}\right)-\frac{k_{\text {ins }}}{x_{\text {ins }}} A\left(T_{\text {wall }}-T_{\text {ins }}\right)
\end{aligned}
$$

The balance across the insulation is

$$
\begin{aligned}
\frac{d}{d t}\left[A x_{\text {ins }} C p_{\text {wall }}\left(\frac{T_{\text {wall }}+T_{\text {ins }}}{2}\right)\right]= \\
\quad \frac{k_{\text {ins }}}{x_{\text {ins }}} A\left(T_{\text {wall }}-T_{\text {ins }}\right)+h_{\text {ins }, \text { surr }} A\left(T_{\text {ins }}-T_{\text {surr }}\right),
\end{aligned}
$$

where: $A$ - heat transfer area, $x$ - thickness, $C p$ - heat capacity, $T$ - temperature, $k$-thermal conductivity, $h$ - heat transfer coefficient.

As shown, both the insulation and wall can store heat. The heat loss term that is accounted for in the energy balance around the holdup is $h_{\text {fluid,wall }} A\left(T_{\text {fluid }}-T_{\text {wall }}\right)$. If $T_{\text {fluid }}$ is greater than $T_{\text {wall }}$, the heat will be lost to the surroundings. If $T_{\text {fluid }}$ is less than $T_{\text {wall }}$, the heat will be gained from the surroundings.

If the vessel level changes, a part of the wall and insulation that was associated with one phase will become part of another. The temperature of the incremental piece of the wall and the bulk of the wall will be equilibrated by the simple averaging

$$
T_{\text {new }}=\frac{T_{1} A+T_{2} \delta A}{A+\delta A},
$$

where: $A$ - heat transfer area of encroaching phase, $\delta A$ - heat transfer area of displaced phase, $T_{1}$ - temperature of encroaching phase, $T_{2}$ - temperature 
of displaced phase.

In a fluid heater, the duty applied to the vessel depends on the liquid level in the tank. The heater height is expressed as a percentage of the liquid level in the vessel operation, the default values are $5 \%$ for the top of the heater and $0 \%$ for the bottom of the heater. These values are used to scale the amount of duty that is applied to the vessel contents:

$$
\begin{array}{ll}
Q=0 & (L<B) \\
Q=\frac{L-B}{T-B} Q_{\text {Total }} & (B \leq L \leq T) \\
Q=Q_{\text {Total }} & (L>T)
\end{array}
$$

where: $L$-liquid percent level, $T, B$-top and bottom of heater, respectively in $\%$.

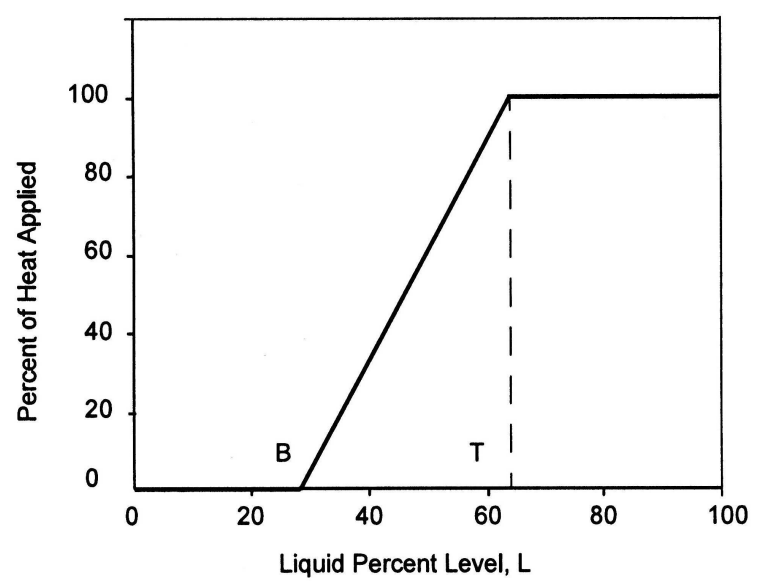

Figure 4: Percent heat applied for a flue gas heater.

The percent heat applied is presented in Fig. 4 and may be calculated as follows:

$$
\text { Percent Heat Applied }=\frac{Q}{Q_{\text {Total }}} \times 100 \%
$$

It is shown that the percent of heat applied to the vessel's holdup directly varies with the surface area of liquid contacting the heater. 


\section{Dynamic oriented model of the boiler}

\subsection{Existing boiler}

SWZ Termo Max [2] is a single coil cylinder with an extra entries for, e.g., external heat exchanger/cylinder with storage capacity $140 \mathrm{l}$. The design and dimensions are presented in Fig. 5. Main parameters of the boiler are given in Tab. 1.

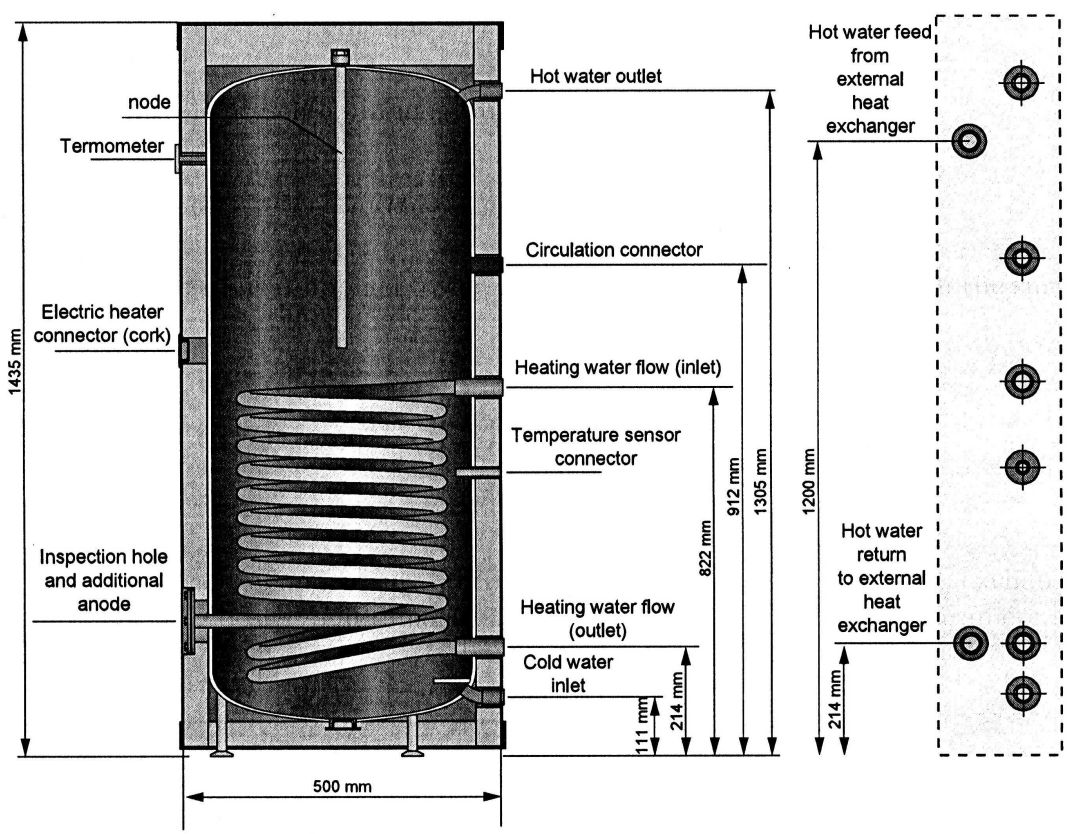

Figure 5: Design and dimensions of the boiler.

\subsection{Boiler model in Hysys software}

In the available literature most of models are made in TRNSYS software [22]. Authors of this paper decided to create model of the boiler in commercial Aspen HYSYS, [28] software.

The model takes into account the following 11 various parameters:

1. Flue gas volumetric, flow rate to the spiral.

2. Flue gas temperature. 
Table 1: Main parameters of the boiler.

\begin{tabular}{|l|r|}
\hline Parameter & Value \\
\hline \hline Volume, $\mathrm{dm}^{3}$ & 140 \\
Spiral heating area, $\mathrm{m}^{2}$ & 1 \\
\hline Spiral volume, $\mathrm{dm}^{3}$ & 4.3 \\
\hline Spiral heat duty, $\mathrm{kW}$ & 37 \\
\hline Heat loss, $\mathrm{kWh} / 24 \mathrm{~h}$ & 1.4 \\
\hline Maximum pressure, $\mathrm{MPa}$ & 0.6 \\
\hline Height, $\mathrm{mm}$ & 1435 \\
\hline Diameter, $\mathrm{mm}$ & 500 \\
\hline
\end{tabular}

3. Flue gas composition.

4. Vessel volume.

5. Insulation thickness.

6. Outlet water flow rate (possible no flow). The flow may be correlated to the inlet water flow.

7. External temperature.

8. Inlet water temperature.

9. Minimum temperature of stored water (emergency heating by flue gas).

10. Maximum temperature of stored water (emergency flue gas closing).

Boiler is described by sizing parameters, nozzle parameters and heat loss including ambient temperature. Heat loss is calculated by manufacturers data $(1.4 \mathrm{kWh} / 24 \mathrm{~h})$. Flue gas volumetric flow rate to the spiral, flue gas composition and flue gas temperature are parameters describing conditions of gas delivering to the spiral. Comparing model and experimental data it can be noticed, that heat loss is calculated correctly. In the geometry parameters can be chosen between 'cylinder' and 'sphere' type. Presented model of the boiler is 'cylinder' type. Choosing 'cylinder' type, it is obligation to choose orientation between 'vertical' and 'horizontal'. The heater height inside the boiler is about $60 \%$ of vessel volume. The analysis were made for 1 zone vessel, 5 zone vessel, 10 zone vessel and 50 zone vessel. Vessel is divided into vertically zones. An example of 50 zone vessel from HYSYS software is presented in Fig. 6. 


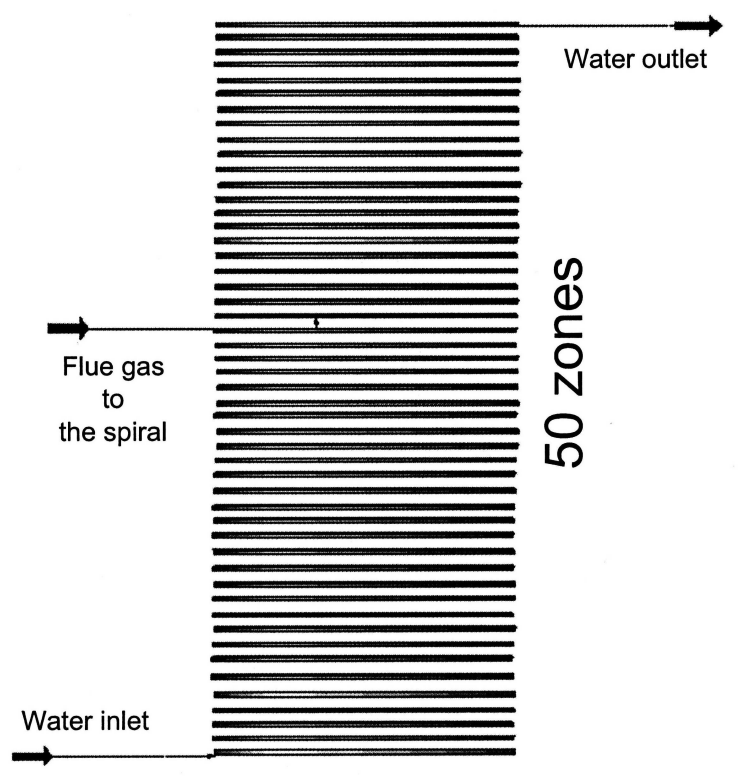

Figure 6: Vessel divided into 50 zones in HYSYS software.

At first the simulation was provided for 1 zone vessel. The result is shown in Fig. 7. The results for 5 zone vessel are shown in the Fig. 8, the result for 10 zone vessel is shown in Fig. 9 and the result for 50 zone vessel is shown in Fig. 10.

\subsection{Comparison between simulation results and experiments}

In Fig. 11 the comparison between simulation results and experiments is shown. The experiments were provided at the Institute of Energy. As can be noticed, the model does not follow the experiment at curve. It is the result of not precisely specified knowledge of starting point during experiments, especially temperatures inside the boiler. The temperatures inside the boiler are stratified. There are only 4 termocouples to describe temperatures in the boiler. All of them are installed outside the boiler, on pipes delivering and removing water and flue gasses (air) from the boiler. Also the selected water flow meter was not enough precise for accurate measurements. Based on this comparison there was a conclusion, that experiments should be repeated. 


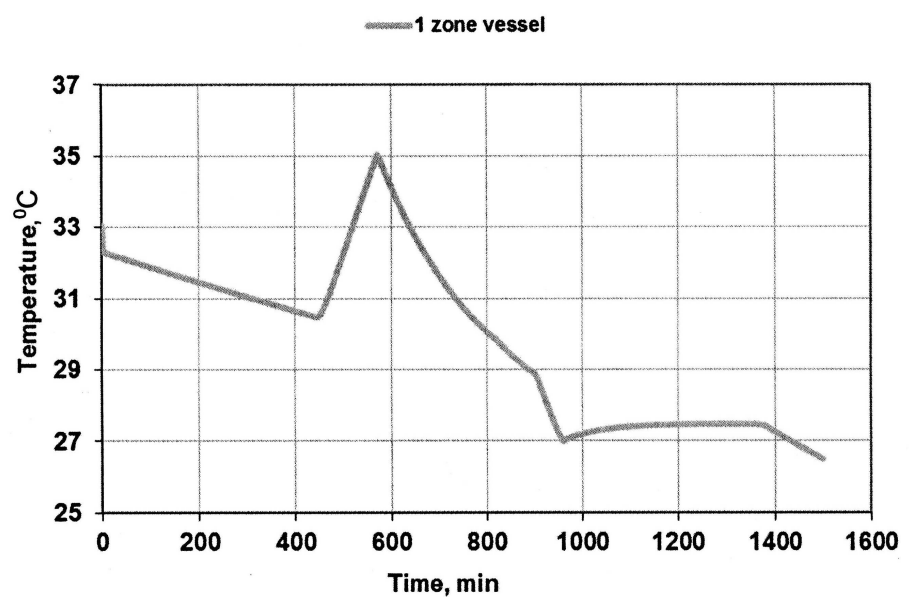

Figure 7: Simulation result for 1 zone vessel.

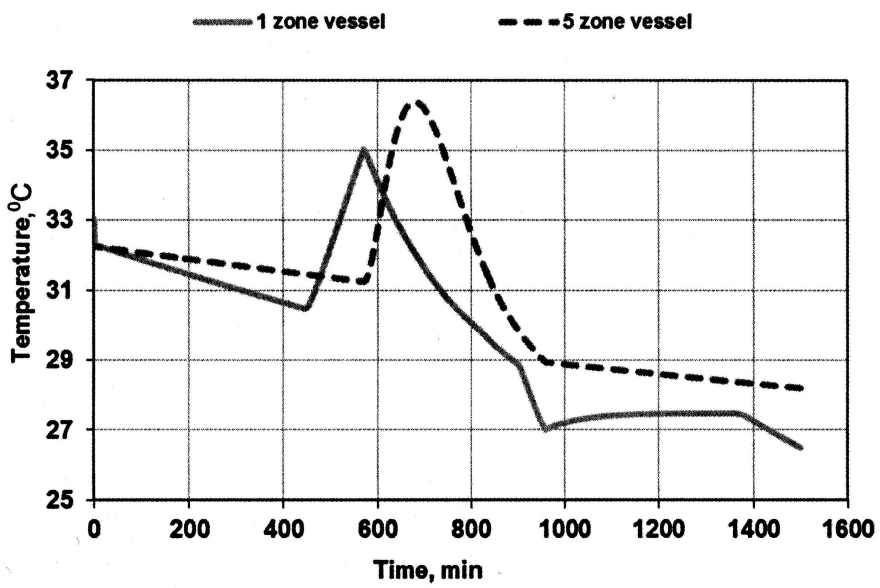

Figure 8: Simulation result for 5 zone vessel.

Authors decided to develop a new experiment with the boiler. First step was to fill the boiler with water. Temperature of the water was about $25^{\circ} \mathrm{C}$. The water was taken from the water supplying system installed at the Institute. Temperature of the water was decreasing. At the beginning the water was heated up probably from the wall temperature (pipes were 


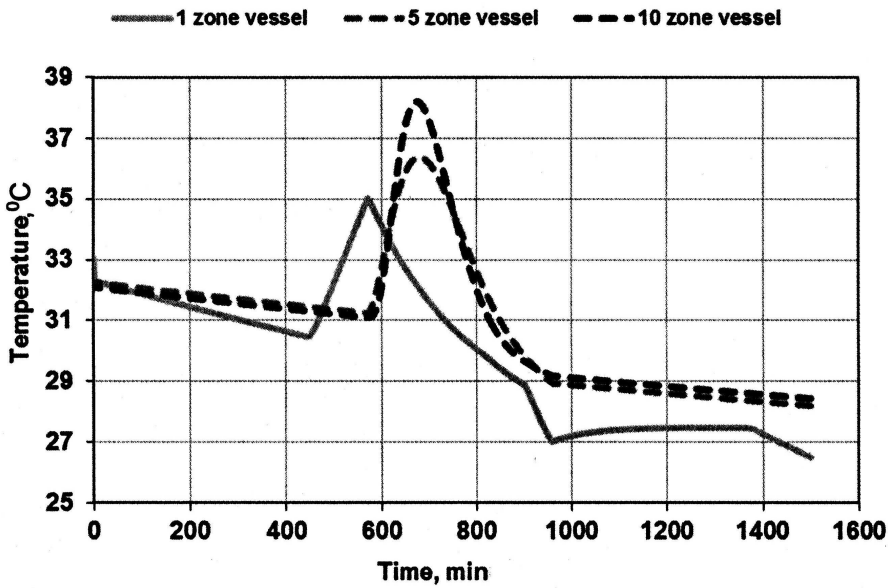

Figure 9: Simulation result for 10 zone vessel

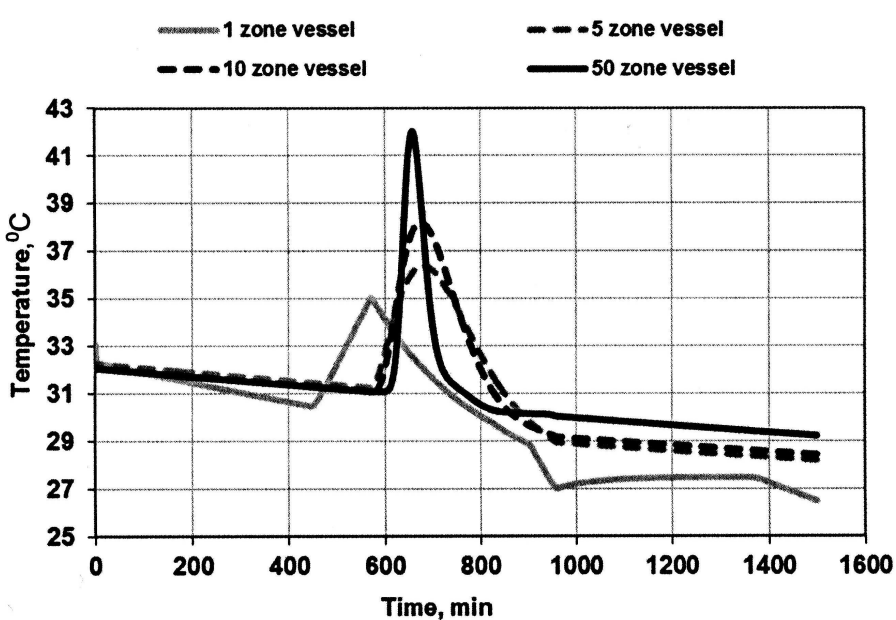

Figure 10: Simulation result for 50 zone vessel.

inside the building). Later, the temperature of the supply water decreased its temperature to the value of about $7.3^{\circ} \mathrm{C}$. The boiler was filled with this water, but outlet temperature of the water (from the boiler) was about $10^{\circ} \mathrm{C}$. During experiments the temperature of the water supplying to the 


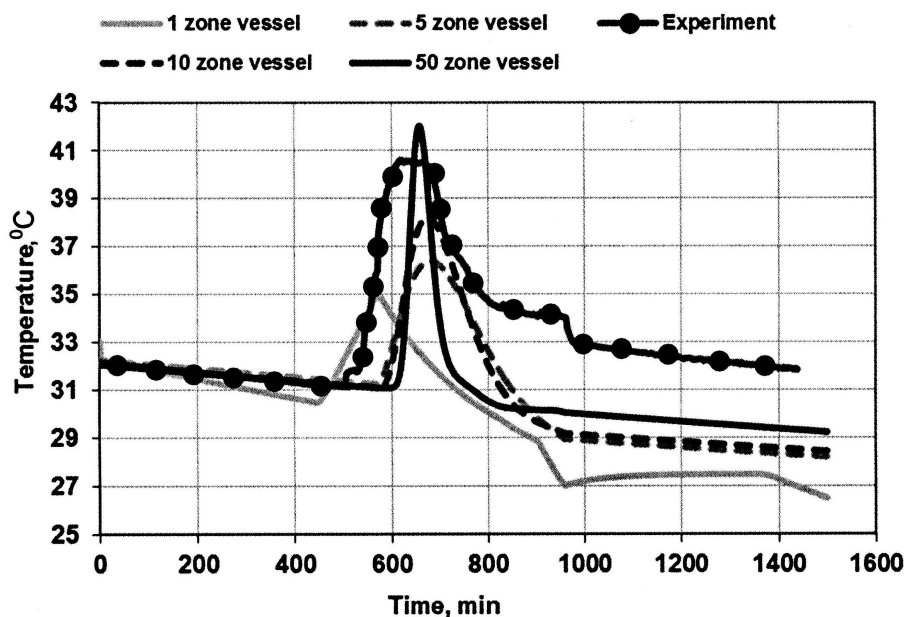

Figure 11: Comparison between experiment and simulations for different zone numbers boiler.

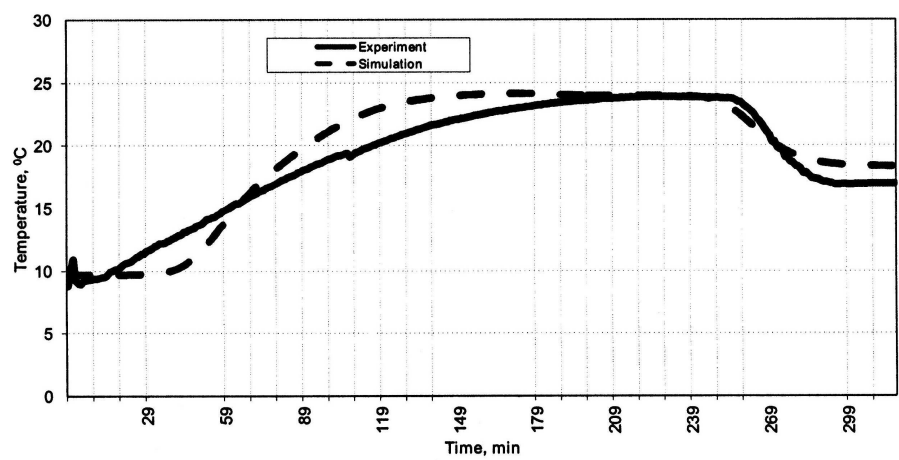

Figure 12: Simulation and experiment comparison.

boiler was about $15^{\circ} \mathrm{C}$. This was the reason of small flow of the water $(75$ $80 \mathrm{~kg} / \mathrm{h}$ ) and water was still heating up from interior of the Institute before was delivered to the boiler. The simulation and experiment comparison is shown in Fig.12. 


\section{Summary}

The dynamic model of the boiler was build using the commercially available software. The comparison between simulation results and experiments has been presented. The experiments were accomplished at the Institute of Energy. As can be noticed, the model follows the experiment a curve, but there are some discrepancies. The reason for differences between experiment and simulation can be caused due to such things, as, e.g., measurement equipment. Different values of water flow from different measuring devices was read: pump $-100 \mathrm{~kg} / \mathrm{h}$; flow meter $-80 \mathrm{~kg} / \mathrm{h}$; own measurements $-87 \mathrm{~kg} / \mathrm{h}$. Also water flow was changing due to leakage in the pump (at the ending of experiments water flow meter showed $75 \mathrm{~kg} / \mathrm{h}$. The experiment started to early after rapidly filling boiler with water (not stable stratification in the boiler at the beginning of experiments). Stratification has been changing in the boiler during experiments (water flow during filling the boiler was many times higher than during experiments).

Received 9 November 2015

\section{References}

[1] Bakalis D., Stamatis A.: Incorporating available micro gas turbines and fuel cell: Matching considerations and performance evaluation. Appl. Energ. 103(2013), 607-617.

[2] Bartela L., Kotowicz J.: Analysis of operation of the gas turbine in a poligeneration combined cycle. Arch. Thermodyn. 34(2013), 4, 137-159.

[3] Buonomano A., Calise F., Accadia M., Palombo A., Vicidomini M.: Hybrid solid oxide fuel cells-gas turbine systems for combined heat and power: A review. Appl. Energ. 156(2015), 32-85.

[4] Corigliano O., Fragiacomo P.: Technical analysis of hydrogen-rich stream generation through $\mathrm{CO}_{2}$ reforming of biogas by using numerical modeling. Fuel 158(2015), 538-548.

[5] De Lorenzo G. Fragiacomo P.: Energy analysis of an SOFC system fed by syngas. Energ. Convers. Manage. 93(2015), 175-186.

[6] Ding J., Li X. CaO, J., Sheng L., Yin L., Xu X.: New sensor for gases dissolved in transformer oil based on solid oxide fuel cell. Sensors and Actuators, B: Chemical 202(2014), 232-239.

[7] Fernández-Seara J., Sieres J. et al.: Experimental analysis of a domestic electric hot water storage tank. Part II: Dynamic mode of operation. Appl. Therm. Eng. $\mathbf{2 7}(2007), 1,137-144$. 
[8] Fernández-Seara J., Uhía F.J., PArdiñas Á.Á., Bastos S: Experimental analysis of an on demand external domestic hot water production system using four control strategies. Appl. Energ. 103(2013), 85-96.

[9] Hegazy A.A., Diab M.: Performance of an improved design for storage-type domestic electrical water-heaters. Appl. Energ. 71(2002), 4, 287-306.

[10] Hosseinzadeh E., Rokni M., Jabbari M., Mortensen H.: Numerical analysis of transport phenomena for designing of ejector in PEM forklift system. Int. J. Hydrogen Energ. 39(2014), 12, 6664-6674.

[11] Huang H., Li J., He Z., Zeng T., Kobayashi N., Kubota M.: Performance analysis of a MCFC/MGT hybrid power system bi-fueled by city gas and biogas. Energies 8(2015), 6, 5661-5677.

[12] Kupecki J., Jewulski J., Badyda K.: Comparative study of biogas and DME fed micro-CHP system with solid oxide fuel cell. Appl. Mech. Materials 267(2013), $53-56$.

[13] Liu A.-G., Weng Y.-W., Chen L., Ma H.-A.: Performance analysis of fuel cell for pressured $M C F C / M G T$ hybrid system. Shanghai Jiaotong Daxue Xuebao/J. Shanghai Jiaotong Univer. 48(2014), 9, 1239-1245.

[14] Mondal S., De S.: Transcritical $\mathrm{CO}_{2}$ power cycle - effects of regenerative heating using turbine bleed gas at intermediate pressure. Energy 87(2015), 95-103.

[15] Pianko-Oprych P., Kasilova E., Jaworski Z.: Quantification of the radiative and convective heat transfer processes and their effect on mSOFC by CFD modelling. Polish J. Chem. Technol. 16(2014), 2, 51-55.

[16] Polverino P., Pianese C., Sorrentino M., Marra D.: Model-based development of a fault signature matrix to improve solid oxide fuel cell systems on-site diagnosis. J. Power Sources 280(2015), 320-338.

[17] Qian J., Tao Z. Xiao, J., Jiang G., Liu W.: Performance improvement of ceriabased solid oxide fuel cells with yttria-stabilized zirconia as an electronic blocking layer by pulsed laser deposition. Int. J. Hydrogen Energ. 38(2013, 5, 2407-2412.

[18] Rabbani A., Rokni M.: Modeling and analysis of transport processes and efficiency of combined SOFC and PEMFC systems. Energies 7(2014),9, 5502-5522.

[19] Ramandi M., Dincer I., Berg P.: A transient analysis of three-dimensional heat and mass transfer in a molten carbonate fuel cell at start-up. Int. J. Hydrogen Energy 39(2014), 15, 8034-8047.

[20] Rexed I., della Pietra M., McPhail S., Lindbergh G., Lagergren C.: Molten carbonate fuel cells for $\mathrm{CO}_{2}$ separation and segregation by retrofitting existing plants - An analysis of feasible operating windows and first experimental findings. Int. J. Greenhouse Gas Control 35(2015), 120-130.

[21] Roshandel R., Astaneh M., Golzar F.: Multi-objective optimization of molten carbonate fuel cell system for reducing CO2 emission from exhaust gases. Front. Energ. 9(2015), 1, 106-114.

[22] Spur R., Fiala D., Nevrala D., Probert D.: Performances of modern domestic hot-water stores. Appl. Energ. 83(2006), 8, 893-910. 
[23] Stempien J., Sun Q., Chan S.: Performance of power generation extension system based on solid-oxide electrolyzer cells under various design conditions. Energy 55(2013), 647-657.

[24] Subotić V., Schluckner C., Mathe J., Rechberger J., Schroettner H. Hochenauer C.: Anode regeneration following carbon depositions in an industrialsized anode supported solid oxide fuel cell operating on synthetic diesel reformate. J. Power Sources 295(2015), 55-66.

[25] WeE J.-H.: Carbon dioxide emission reduction using molten carbonate fuel cell systems. Renew. Sust. Energy Rev. 32(2014), 178-191.

[26] Xu H., DANG Z., BAI B.-F.: Electrochemical performance study of solid oxide fuel cell using lattice Boltzmann method. Energy 67(2014), 575-583.

[27] Zhang X., Liu H., Ni M., Chen J.: Performance evaluation and parametric optimum design of a syngas molten carbonate fuel cell and gas turbine hybrid system. Renew. Energ. 80(2015), 407-414.

[28] Aspen HYSYS User Guide, 2005. 